\title{
Fouling in Plate Heat Exchangers: Some Practical Experience
}

\author{
Ali Bani Kananeh and Julian Peschel \\ GEA PHE Systems \\ Germany
}

\section{Introduction}

Due to their compact size, Plate Heat Exchangers (PHEs) are widely used in industrial processes. They have higher heat-transfer performance, lower temperature gradient, higher turbulence, and easier maintenance in comparison with shell and tube heat exchangers. For minimizing material consumption and space requirements compact models have been developed over the last years. By using thin plates forming a small gap, these compact models impress with larger heat transfer coefficients and, thus, smaller required heat transfer area.

The advantages of compact heat exchangers over shell and tube ones at a glance:

- larger heat transfer coefficients

- smaller heat transfer surfaces required

- lower fouling due to high fluid turbulences (self-cleaning effect)

- $\quad$ significantly smaller required installation and maintenance space

- lighter weight

- $\quad$ simplified cleanability especially for GPHE

- lower investment costs

- closer temperature approach

- $\quad$ pure counter-flow operation for GPHE

In Figure 1, plate heat exchangers are compared with shell and tube heat exchangers regarding effectiveness, space, weight and cleaning time.

Deposits create an insulating layer over the surface of the heat exchanger that decreases the heat transfer between fluids and increases the pressure drop. The pressure drop increases as a result of the narrowing of the flow area, which increases the gap velocity (Wang et al., 2009). Therefore, the thermal performance of the heat exchanger decreases with time, resulting in an undersized heat exchanger and causing the process efficiency to be reduced. Heat exchangers are often oversized by 70 to $80 \%$, of which 30 to $50 \%$ is assigned to fouling. While the addition of excess surface to the heat exchanger may extend the operation time of the unit, it can cause fouling as a result of the over-performance caused by excess heat transfer area; because the process stream temperature change greater than desired, requiring that the flow rate of the utility stream be reduced (Müller-Steinhagen, 1999). The deposits 


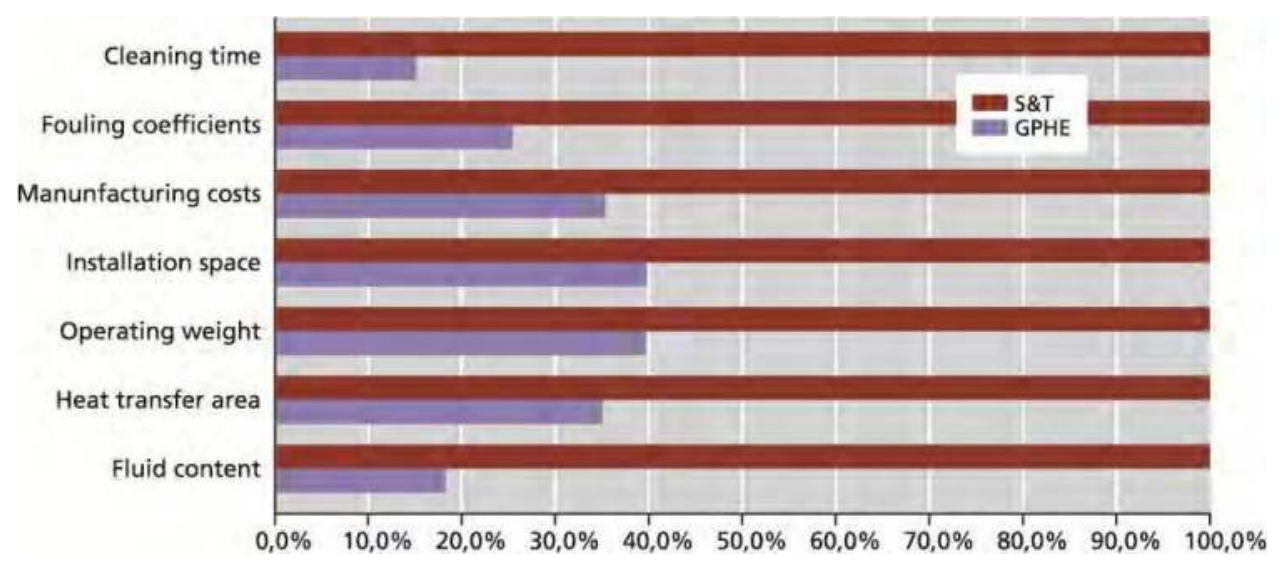

Fig. 1. Comparison of plate heat exchanger with shell and tube heat exchanger.

must be removed by regular and intensive cleaning procedures in order to maintain production efficiency.

As a result of the effects of fouling on the thermal and hydraulic performance of the heat exchanger, an additional cost is added to the industrial processes. Energy losses, lost productivity, manpower and cleaning expenses cause immense costs. The annual cost of dealing with fouling in the USA has been estimated at over $\$ 4$ billion (Wang et al., 2009).

The manner in which fouling and fouling factors apply to plate exchangers is different from tubular heat exchangers. There is a high degree of turbulence in plate heat exchanger, which increases the rate of deposit removal and, in effect, makes the plate heat exchanger less prone to fouling. In addition, there is a more uniform velocity profile in a plate heat exchanger than in most shell and tube heat exchanger designs, eliminating zones of low velocity which are particularly prone to fouling. Figure 2 shows the fouling resistances for cooling water inside a plate heat exchanger in comparison with fouling resistances on the tube-side inside a shell and tube heat exchanger for the same velocity. A dramatic difference in the fouling resistances can be seen. The fouling resistances inside the PHE are much lower than that inside the shell and tube heat exchanger.

Fouling inside heat exchanger can be reduced by:

- Appropriate heat-exchanger design

- Proper selection of heat-exchanger type

- Mitigation methods (mechanical and/or chemical)

- Heat exchanger surface modification/coating

The mechanics of deposits build-up and the impact of operating conditions on the deposition rate should be understood in order to select the appropriate method to reduce fouling (Müller-Steinhagen, 1999). 


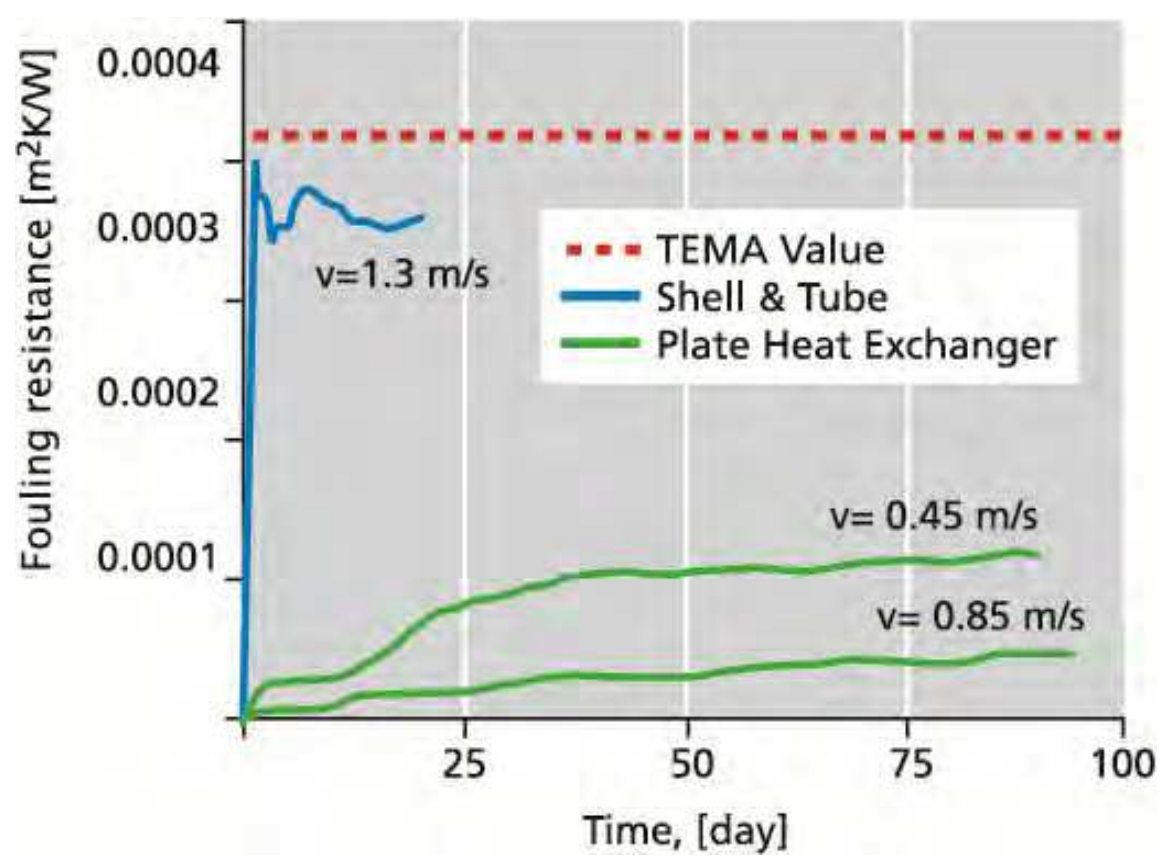

Fig. 2. Comparison of fouling resistance in PHE to tube-side fouling resistance (MüllerSteinhagen, 2006).

This chapter focuses on solving fouling problems in some industrial applications. The first section presents fouling problems with cooling water inside $\mathrm{CO}_{2}$ coolers in different Egyptian fertilizer plants. The effect of heat exchanger geometry and flow patterns on the fouling behavior will be shown. Thermodynamic and hydraulic solutions are proposed like, redesigning of the plate heat exchangers and new plate geometries. The second section explains how fouling can be reduced inside gasketed plate heat exchangers used in food production using Nano-composite coatings. An antifouling coating with low surface energy (low wettability) can be used to avoid or minimize adhesion, improve process management, simplify cleaning processes with less resources and chemical use, and increase product reliability. The operational efficiency of the plant can be significantly improved and the intensity and frequency of cleaning can be substantially reduced.

\section{Solving fouling problems by heat exchanger design modification}

Fouling problems with cooling water inside $\mathrm{CO}_{2}$ coolers in different Egyptian fertilizer plants were investigated. Thermodynamic and hydraulic solutions were proposed, which included redesign of the existing PHEs and new plate geometries. The main problems arose from the large surface margins required to meet pressure drop limits on the $\mathrm{CO}_{2}$ side. Reducing the surface area of the heat exchanger increased the fluid velocity (shear stress from 5.31 to $10.84 \mathrm{~Pa}$ ) inside the gaps and hence decreased fouling. Using computer- 
modeled plate geometries from the new technology (NT) series with larger gap velocities due to better fluid distribution over the plates could decrease fouling and increase the availability of fertilizer plants.

\subsection{Introduction}

To guarantee production reliability in the complex urea fertilizer manufacturing process, PHEs are installed in several process chains including $\mathrm{CO}_{2}$ cooling, residual gas scrubbing, and other process sections as were as in the primary urea production plant. Industrial processes commonly use water for cooling purposes. Open circuit cooling system is used in some processes, while closed loop system involving cooling towers is used in others. Closed loop systems usually cause less fouling than open ones, but they are more expensive (Kukulka and Leising, 2009). Cooling water normally contains dissolved or suspended solids like calcium carbonate and calcium sulphate. If the concentration of these dissolved solids exceeds certain limits, it leads to the accumulation of deposits on the heat exchanger surface (Müller-Steinhagen, 1999). These deposits create an insulating layer on the surface of the heat exchanger that decreases the heat transfer between the two fluids. The thermal performance of the unit decreases with time as the thickness of the deposit increases, resulting in an undersized heat exchanger and causing the process efficiency to be reduced (Kukulka and Leising, 2009). Deposit formation can be reduced either by changing the configuration of the heat exchanger or by regular cleaning procedures.

Deposit formation is influenced by the heat exchanger surface and geometry, cooling medium and the operating conditions. Its composition depends on the flow rate, temperature and chemical composition of the cooling medium (Kukulka and Leising, 2009). Pana-Suppamassadu et al. (2009) studied the effect of plate geometry (contact angle) and the gap velocity on calcium carbonate fouling in plate heat exchanger. They found that an increase in the gap velocity could reduce the fouling rate on the surface of plate heat exchanger.

In the present section, deposit formation on the surface of plate heat exchangers in different Egyptian fertilizer plants will be investigated. The effect of heat exchanger geometry and flow patterns on the fouling behavior will be shown.

\subsection{Process description}

Ammonia is the basic raw material in urea production. Ammonia plants in question operate using Uhde's proprietary ammonia process that is based on the well-established HaberBosch process. In the first stage, the raw material natural gas is desulphurized, then cracked into its individual chemical components catalytically by adding steam to generate the hydrogen required for ammonia synthesis. This process also generates carbon monoxide, carbon dioxide, hydrogen and residues of methane from the natural gas cracking process. In the next stage nitrogen is added to the process by combusting methane, $\mathrm{CO}$ and $\mathrm{H}_{2}$ using air. With the addition of steam, carbon monoxide is converted to $\mathrm{CO}_{2}$ using catalytic converters and then scrubbed out of the synthesis gas formed. The selectively scrubbed $\mathrm{CO}_{2}$ is fed into the urea processing plant as the process medium together with the produced ammonia as starting material. The urea plants operate using the Stamicarbon process that was developed in the Netherlands [Uhde]. 


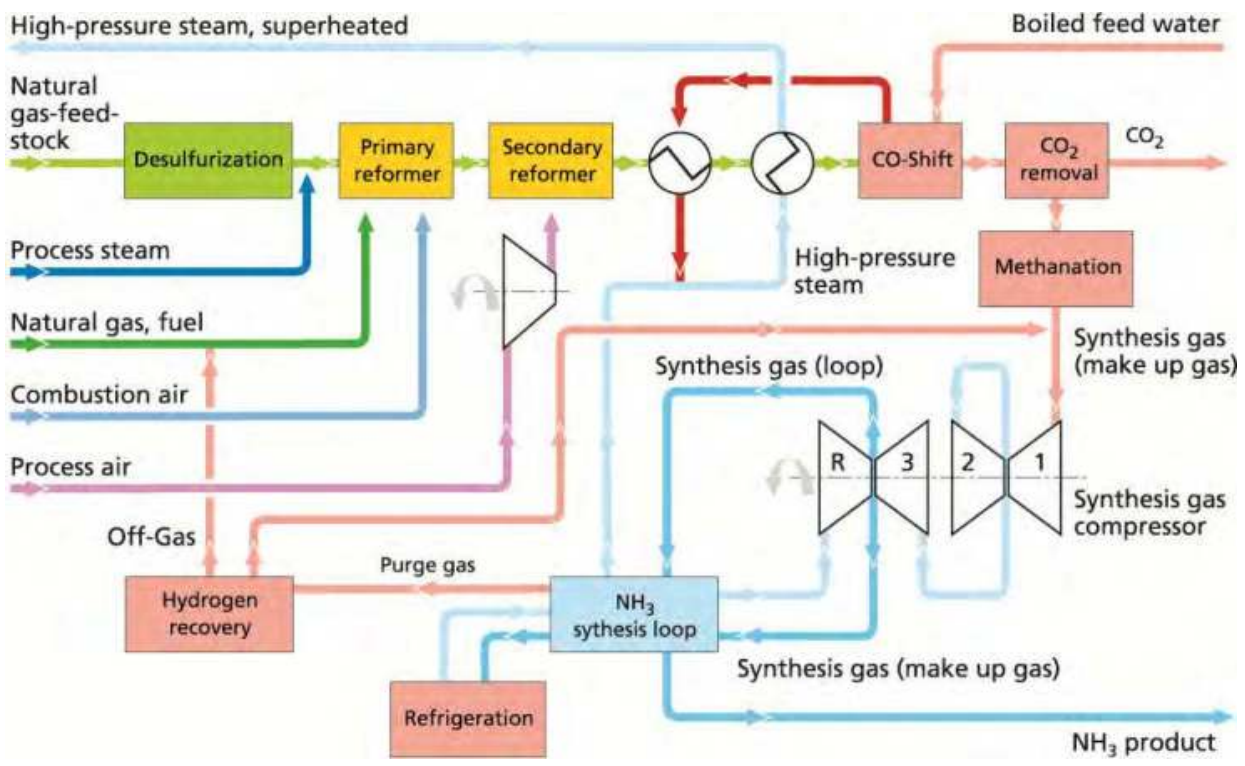

Fig. 3. Ammonia process [Uhde].

In the $\mathrm{CO}_{2}$ scrubbing process three plate heat exchangers are switched in parallel, two in operation (A and B) and one in standby (C). Figure 4 shows the three coolers with their operating conditions. The $\mathrm{CO}_{2}$ flows into the PHEs as a gas-steam mixture at $94{ }^{\circ} \mathrm{C}$ and is cooled down in a countercurrent process to $33^{\circ} \mathrm{C}$. Water at $30^{\circ} \mathrm{C}$ is used as coolant. Each of the 10 tons and 3 meter high PHEs has $1000 \mathrm{~m}^{2}$ of high-performance stainless steel (1.4539; AISI 904 L) VT-plates. The transferred heat capacity is 14.5 megawatts.

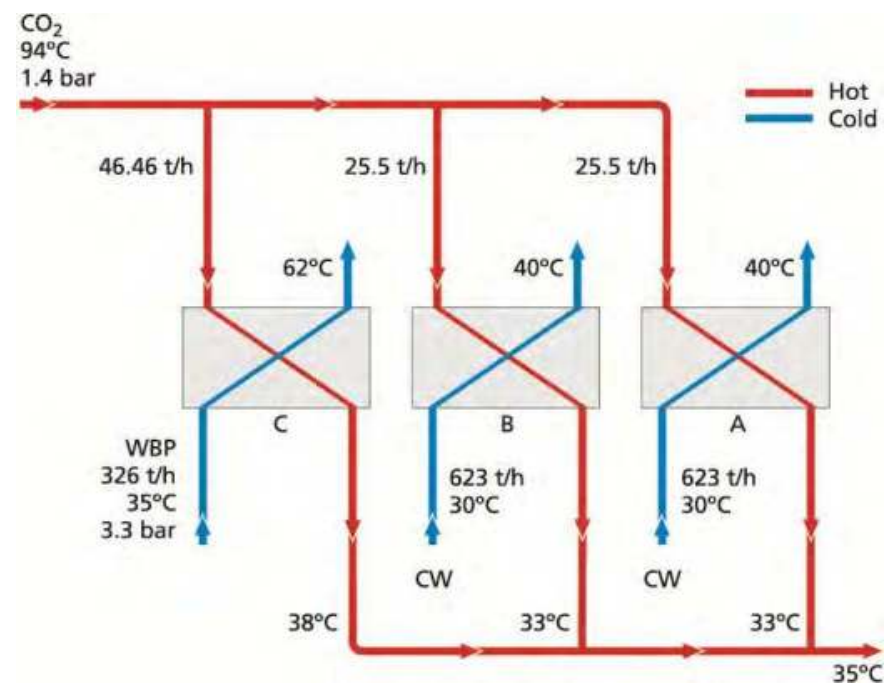

Fig. 4. $\mathrm{CO}_{2}$ coolers used in the scrubbing process. 
Nile river water treated by NALCO inhibitors is used in an open loop as the cooling medium for the $\mathrm{CO}_{2}$ coolers, the specifications of the cooling water used is given in Table 1 .

\begin{tabular}{|c|c|c|c|c|}
\hline & CaH & Alkalinity & Chlorides & Inhibitors \\
\hline Nile water & $90 \mathrm{ppm}$ & 138 & $25 \mathrm{ppm}$ & $\begin{array}{c}\text { N-7356P: 30ppm, } \\
\text { N-73203: 95ppm }\end{array}$ \\
\hline
\end{tabular}

Table 1. Cooling water specifications.

A typical analysis for Nile river water is shown in Table 2.

\begin{tabular}{|l|c|c|}
\hline Substrate & & Unit \\
\hline Chloride & 77.5 & ppm \\
\hline $\mathbf{C a}$ & 48 & $\mathrm{ppm}$ \\
\hline $\mathbf{M g}$ & 14.5 & $\mathrm{ppm}$ \\
\hline $\mathbf{N a}$ & 60 & $\mathrm{ppm}$ \\
\hline $\mathrm{K}$ & 9 & $\mathrm{ppm}$ \\
\hline $\mathrm{Fe}$ & 0.1 & $\mathrm{ppm}$ \\
\hline $\mathrm{SO}_{4}$ & 57.5 & $\mathrm{ppm}$ \\
\hline $\mathrm{SiO}_{2}$ & 2 & $\mathrm{ppm}$ \\
\hline $\mathrm{HCO}_{3}$ & 180 & $\mathrm{ppm}$ \\
\hline $\mathrm{KMnO}_{4}$ & 10.1 & $\mathrm{ppm}$ \\
\hline Total hardness & 172.5 & $\mathrm{ppm} \mathrm{CaCO}$ \\
\hline TDS & 380 & $\mathrm{ppm}$ \\
\hline pH & 7.8 & - \\
\hline Alkalinity & 180 & $\mathrm{ppm} \mathrm{CaCO}$ \\
\hline
\end{tabular}

Table 2. Nile river water analysis.

\subsection{Problem description and observations}

The cooling water flow rate on the $\mathrm{CO}_{2}$ coolers (HP Scrubber) dropped from $500 \mathrm{~m}^{3} / \mathrm{hr}$ to $300 \mathrm{~m}^{3} / \mathrm{hr}$ due to fouling on the cooling water side, which caused operation problems in the Urea plant. The $\mathrm{CO}_{2}$ outlet temperature was increasing with time and achieved about $50^{\circ} \mathrm{C}$ after 30 days of operation before the shutdown of the unit for mechanical cleaning. The $\mathrm{CO}_{2}$ cooler was opened for mechanical cleaning; the PHE's inlet was plugged with plastic bags and pieces of bottles. Deposits were accumulated at an area about $20 \mathrm{~cm}$ from the plate inlet and selectively covered the plate surface, as can be seen in Figure 5. They could plug the channels and restrict the water flow over the plate. These deposits accumulated due to the reduction of the gap velocity (shear stress) which increased the surface temperature.

A sample from the deposits was taken and analysed using ashing and X-ray Fluorescence (XRF). The sample was dried at $105{ }^{\circ} \mathrm{C}$ before ashing and $\mathrm{XRF}$ analysis. The results are shown in Table 3.

The ashing results showed that $14 \%$ of the sample was lost at a temperature below $500^{\circ} \mathrm{C}$, which represents the organic material and can be considered as normal range. The XRF analysis showed that the main element in the deposits is zinc hydroxide as $\mathrm{ZnO}(38 \%)$ and 


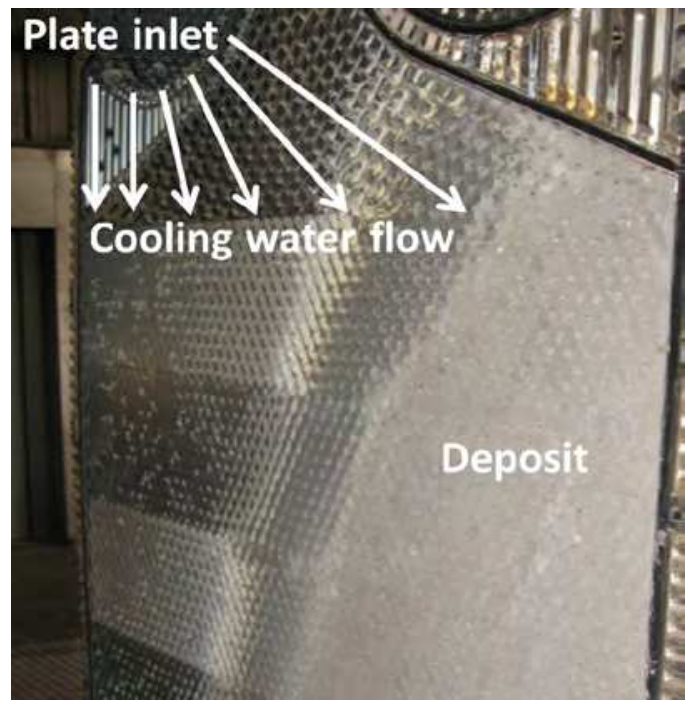

Fig. 5. Deposits formed on the surface of VT-plate.

the second is calcium phosphate $(11 \%)$, which participated as a result of the increase of the plate surface temperature resulting from the reduction in the cooling water flow rate.

\begin{tabular}{|l|l|}
\hline Loss at $500^{\circ} \mathrm{C}$ & $14 \%$ \\
\hline Loss at $925^{\circ} \mathrm{C}$ & $23 \%$ \\
\hline
\end{tabular}

(a)

\begin{tabular}{|l|l|}
\hline Substrate & Mass \% \\
\hline Magnesium $(\mathrm{MgO})$ & 3 \\
\hline Aluminium $\left(\mathrm{Al}_{2} \mathrm{O}_{3}\right)$ & 1 \\
\hline Silicon $\left(\mathrm{SiO}_{2}\right)$ & 2 \\
\hline Phosphorous $\left(\mathrm{P}_{2} \mathrm{O}_{5}\right)$ & 20 \\
\hline Sulphur $\left(\mathrm{SO}_{3}\right)$ & 1 \\
\hline Calcium $(\mathrm{CaO})$ & 11 \\
\hline Iron $\left(\mathrm{Fe}_{2} \mathrm{O}_{3}\right)$ & 1 \\
\hline Zinc $(\mathrm{ZnO})$ & 38 \\
\hline Total oxides (normalized to loss $\left.925^{\circ} \mathrm{C}\right)$ & 77 \\
\hline
\end{tabular}

(b)

Table 3. (a) Ashing results, (b) Elemental analysis as oxides using XRF.

\subsection{Technical solutions}

\subsubsection{Redesigning of the PHEs}

The surface area of the $\mathrm{CO}_{2}$ cooler was reduced by removing 86 plates out of 254 plates (the surface area was reduced by $34 \%$ ). The average cooling water velocity inside the gaps was increased from 0.30 to $0.42 \mathrm{~m} / \mathrm{s}$, as can be seen in Table 4 . 


\begin{tabular}{|l|c|c|}
\hline & Original Design & After modification \\
\hline Plates number & 254 & 168 \\
\hline Gap velocity $[\mathrm{m} / \mathrm{s}]$ & 0.30 & 0.42 \\
\hline Surface tension $[\mathrm{Pa}]$ & 5.31 & 10.84 \\
\hline Reynolds number & 3259 & 4599 \\
\hline Surface temperature $\left[{ }^{\circ} \mathbf{C}\right]$ & 72 & 69 \\
\hline
\end{tabular}

Table 4. Design modification for $\mathrm{CO}_{2}$ cooler in Helwan fertilizer plant, Egypt.

The deposits formed on the surface of the plates were decreased as a result of the increase in the shear stress and the decrease of the surface temperature from 72 to $69^{\circ} \mathrm{C}$. The surface temperature was calculated from the fluids temperatures, thermal conductivities and duties on both sides. The operation time for the cooler was increased from 30 days to 43 days and the plates were cleaned after more than 40 days of operation, as shown in Figure 6.

The $\mathrm{CO}_{2}$ outlet temperature started to increase after about 23 days of operation due to the accumulation of deposits on the cooling water side which led to a reduction in the cooling water flow rate. The unit was opened after about 43 days for mechanical cleaning.

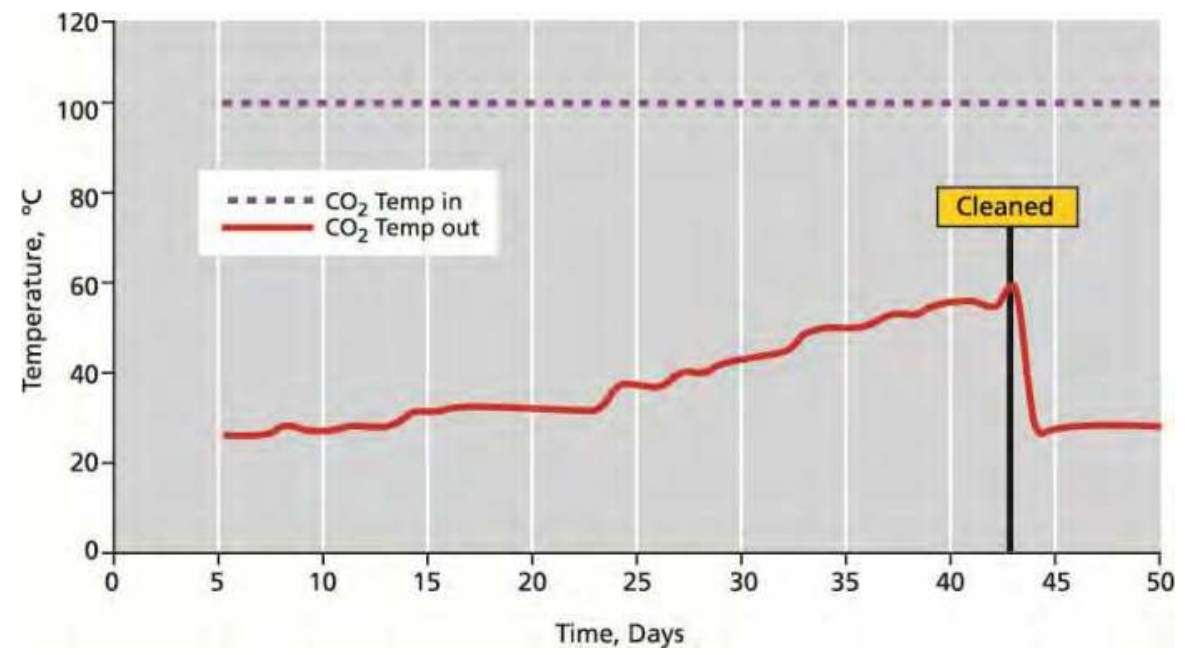

Fig. 6. Inlet and outlet $\mathrm{CO}_{2}$ temperatures as a function of time.

\subsubsection{New plate geometry}

A new cooler with computer-modeled plate geometry from the NT (New Technology) series was installed in parallel with the existing two coolers. The NT Series sets new economic 
standards with low investment costs, operation and maintenance. The optimized OptiWave plate design requires less heat transfer surface for the same performance. The new EcoLoc gaskets and installation methods simplify maintenance and ensure a perfect fit of the gasket and plate packs. The new plates have the advantage of higher gap velocities (shear stress) due to better fluid distribution over the plates and smaller gap size.

The advantages of the NT-plates at a glance:

- High heat transfer rates

- Low investment and service costs

- Optimized distribution of media

- Simplified handling

- Quick and safe gasket replacement

- Flexible solutions for special requirements

- Non-standard materials available

- Leading manufacturer's know-how

In conventional plates the fluid velocity over the plate's width is decreasing, the more the fluid is distributed from the inlet over the whole plate width. This is due to the higher pressure drop in longer flow channels. The optimized fluid distribution channels of the NT series lead to balanced velocity over the whole plate width and an equal distribution of the medium (Figure 7).

The flow channels of the NT-plates vary in their width and were optimized based on Computational Fluid Dynamics (CFD). The channels located further away from the inlet hole have bigger diameter than those closer to the inlet hole.

Fewer deposits were accumulated on the NT-plates due to the asymmetric flow distribution over the channels as can be seen in Figure 8. These deposits were formed because the unit was taken into operation in parallel with the old two VT-plates units and hence most of the cooling water was flowing inside them. The NT-plates unit was designed in principle to replace one of the VT-plates units so that the gap velocity could be increased.
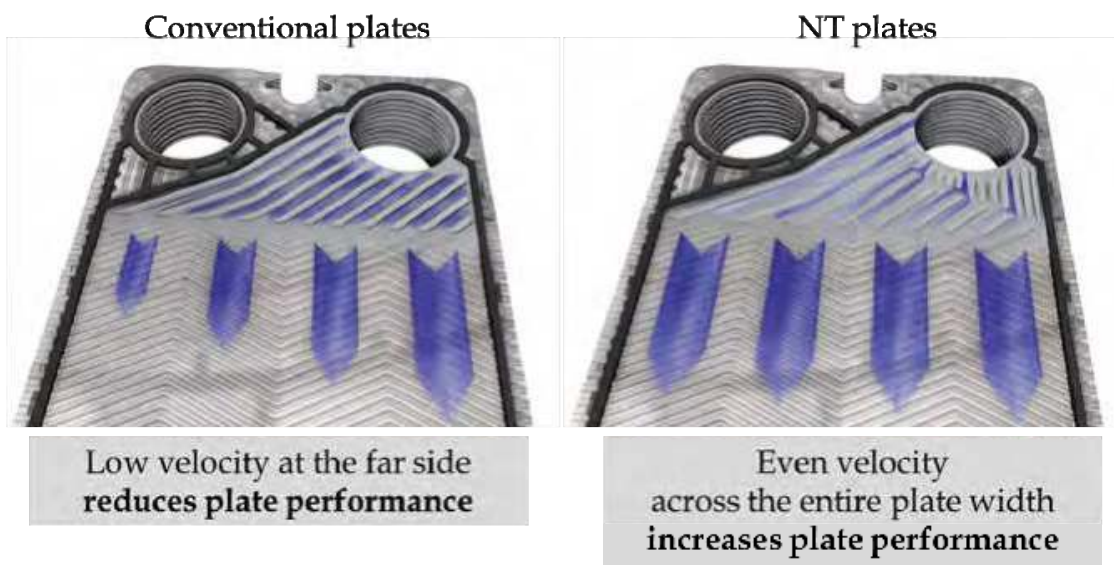

Fig. 7. Velocity distribution over the NT-plate compared with conventional plates. 


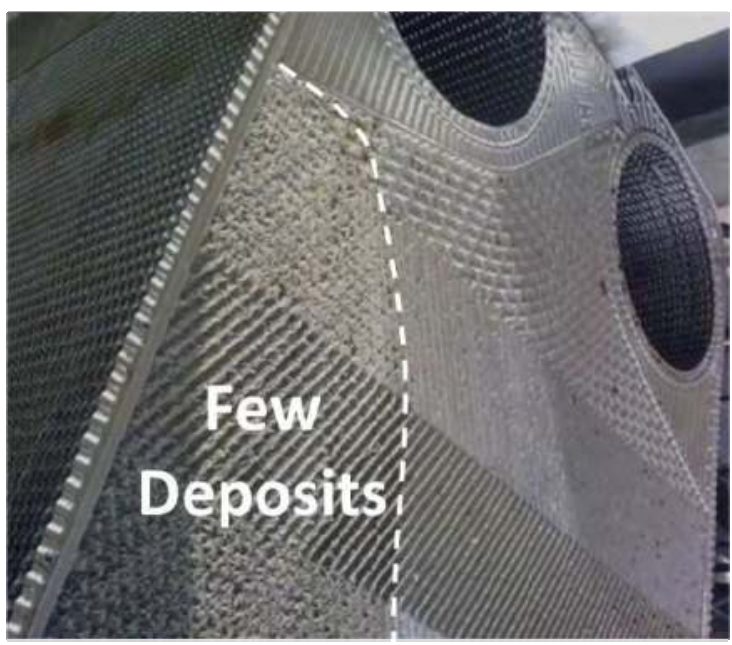

Fig. 8. Deposits formed on the surface of NT-plate.

\subsection{Conclusions}

Nile water treated with NALCO inhibitors caused fouling problems inside $\mathrm{CO}_{2}$ coolers in different Egyptian ammonia plants. Technical solutions including redesigning of the PHEs and new plate geometries were investigated. Reducing the surface area of the $\mathrm{CO}_{2}$ coolers by $34 \%$ increased the gap velocity from 0.30 to $0.42 \mathrm{~m} / \mathrm{s}$ (shear stress from 5.31 to $10.84 \mathrm{~Pa}$ ) and hence decreased fouling. The operation time for the cooler was increased from 30 days to 43 days. NT-plates with asymmetric flow distribution over the channels decreased the rate of deposition on the surface of the plates.

\section{Solving fouling problems by surface modification}

In a recent study, Nano-composite coatings were used to reduce fouling inside gasketed plate heat exchangers involved in food production. An antifouling coating with low surface energy (low wettability) led to a hydrophobic and oleophobic effect. The goal of the project was the application of new surface coatings (nanotechnology) to avoid or minimize adhesion, improve process management, simplify cleaning processes with lesser resources and chemical use, and increase the product reliability.

The test facility constructed by the Institute of Environmental Process Engineering (IUV) at the University of Bremen in Germany used for the investigation of milk adhesion and the stability of the coatings on small cylindrical ducts. A number of coatings and surface treatments were tested. A pilot plant including a milk pasteurizer at the Institute of Food Quality LUFA Nord-West in Oldenburg-Germany was used for the thermal treatment of whey protein solutions. Heat exchanger plates coated with different nano-composites as well as electropolished plates installed in the heating section of the pasteurizer were tested. Significant differences were observed between coated and uncoated plates. The coated plates showed reduced deposit buildup in comparison with the uncoated stainless steel plates. Polyurethane-coated plates exhibited the thinnest deposit layer. Electro-polished 
plates also reduced deposit buildup in comparison to the standard stainless steel plates and were almost comparable to the coated plates. The time required for cleaning in place (CIP) with the coated plates was reduced by $70 \%$ compared to standard stainless steel plates.

\subsection{Introduction}

Production problems, like decrease of production rate and increase in the intensity of cleaning procedure, arise in the dairy industry as a result of the deposit adhesion to the plate surface. The deposits must be removed by regular and intensive cleaning procedures in order to comply with hygiene and quality regulations for the dairy industry (Augustin et al., 2007). If not controlled carefully, deposits can cause deterioration in the product quality because milk cannot be heated up to the required pasteurization temperature. Milk deposits generally form so fast that heat exchangers must be cleaned regularly to maintain production efficiency and meet strict hygiene standards and regulations (Bansal and Chen, 2006). Energy losses, lost productivity, manpower and cleaning expenses cause immense costs (Beuf et al., 2003). In the dairy industry, fouling and the resulting cleaning of the process equipment account for about $80 \%$ of the total production costs (Bansal and Chen, 2006).

Gasketed plate heat exchangers with stainless steel plates are commonly used in the dairy industry. Stainless steel surfaces have high surface energies. The adhesion of product on solid surfaces is determined by the surface roughness and surface energy. The adhesion of deposits could be reduced by either decreasing the surface energy of the metal or by coating the metal surface with high anti-adhesion effect (low surface energy) materials, such as those made of nanoparticles (Gerwann et al., 2002). The application of nano-coatings with their anti-adhesion effects reduces the buildup of deposits on the surface of heat exchanger plates due to the reduction of adhesive forces. The operation efficiency of the plant can be significantly improved and the general hygienic situation of the product can increase. Additionally, intensity and frequency of cleaning can be substantially reduced to achieve the desired degree of product quality (Kück et al., 2007).

Beuf et al. (2003) studied the fouling of dairy product on modified stainless steel surfaces in a plate and frame heat exchanger. Different surface modifications, such as coatings (diamond like carbon [DLC], silica, SiOX, Ni-P-PTFE, Excalibur, Xylan) and ion implantation ( $\mathrm{SiF}+, \mathrm{MoS} 2)$ were analyzed. No significant difference was found between the modified stainless steels and the unmodified one. The cleaning efficiency of plates coated with Ni-P-PTFE was the best. The experimental results of Zhao et al. (2007) showed that the surface free energy of the Ni-P-PTFE coating had a significant influence on the adhesion of bacterial, protein and mineral deposits. The Ni-P-PTFE coating reduced the adhesion of these deposits significantly.

The fouling behavior of whey protein solutions on modified stainless steel (SS) surfaces coated with diamond-like carbon (DLC) and titanium nitride (TiN) have been studied by Premathilaka et al. (2007). They concluded that fouling decreased in the order DLC > SS > TiN and cleaning time decreased in the order TiN $>$ SS $>$ DLC.

The goal of the present work is to assess new surface coatings (developed by the Institute of New Materials, INM, in Germany) with low surface energy and low roughness to avoid or minimize adhesion of deposits, simplify cleaning processes, reduce resource and chemical 
requirements, and increase product quality and consistency. The work will assess the deposit buildup during the thermal treatment of milk.

\subsection{Experimental}

\subsubsection{Coated surfaces}

The anti-adhesion nano-composite coatings, with hydrophobic and oleophobic effectiveness, used in this work were produced from commercially available polymer matrices such as epoxy, polyurethane or Polyamide systems which were reactively cross-linked with perfluorinated monomers (or oligomers) and ceramic reinforcement particles. The coating material application was similar to wet chemical coating by spraying, and the required mechanical properties were obtained through a thermal cross linking step. The epoxy and polyurethane systems were hardened at $130^{\circ} \mathrm{C}$ for 1 hour, while the Polyamide systems were hardened at $200{ }^{\circ} \mathrm{C}$ for 2 hours, in order to ensure an optimum layer formation. Table 5 summarizes the plates used and their specifications.

\begin{tabular}{|l|l|c|c|c|}
\hline Plate & Material & $\begin{array}{c}\text { Contact angle } \\
\text { Water }\left[^{\circ}{ }^{\circ}\right.\end{array}$ & $\begin{array}{c}\text { Contact angle } \\
\left.\mathbf{M i l k}^{\circ}{ }^{\circ}\right]\end{array}$ & $\begin{array}{c}\text { Surface roughness } \\
{[\boldsymbol{\mu m}]}\end{array}$ \\
\hline U1 & Stainless steel & 83.8 & 69.6 & 0.80 \\
\hline U1min,e & $\begin{array}{l}\text { Electrically-polished stainless steel } \\
\text { for one minute }\end{array}$ & 61.7 & 93.5 & 0.50 \\
\hline U5min,e & $\begin{array}{l}\text { Electrically-polished stainless steel } \\
\text { for five minutes }\end{array}$ & 60.3 & 87.8 & 0.22 \\
\hline A1 & Epoxy-resin based coating of INM & 97.6 & 94.5 & 0.92 \\
\hline A2 & Epoxy-resin based coating of INM & 91.0 & 97.6 & 0.95 \\
\hline A9 & Polyurethane based coating of INM & 92.2 & 88.3 & 0.23 \\
\hline A10 & Polyurethane based coating of INM & 93.4 & 95.5 & 0.06 \\
\hline A17 & Epoxy-resin based coating of INM & 95.8 & 95.1 & 1.14 \\
\hline
\end{tabular}

Table 5. Contact angle and surface roughness of the sheets prepared by INM.

\subsubsection{Laboratory scale testing}

A laboratory facility was constructed by the Institute of Environmental Process Engineering (IUV), University of Bremen in Germany, for the investigation of milk adhesion. A heat exchanger was designed to enable thermal and hydraulic load measurements with variable designs. Its principal components were a double wall heated receiver tank, controllable pump, electromagnetic flow meter and the test cell (duct). A closed loop recirculation configuration was used to decrease the volume of the test medium required. Furthermore, a fast sample change by simple removal of the test cell (duct) was performed. Figure 9 shows the laboratory apparatus used and the test duct. The test channel employs an annular geometry, where the inner cylinder is engaged with an electric heater. The middle part (with the threaded ends) is made of stainless steel, while the coin section (right) and the fastener (left) are made from a high-performance plastic Polychlorotriflouroethylene (PCTFE). This arrangement allows the middle section, which incorporates the heater, to be heated by thermal conduction without large heat losses. The coating material is applied to a small stainless steel tube which is pushed over the heater. 


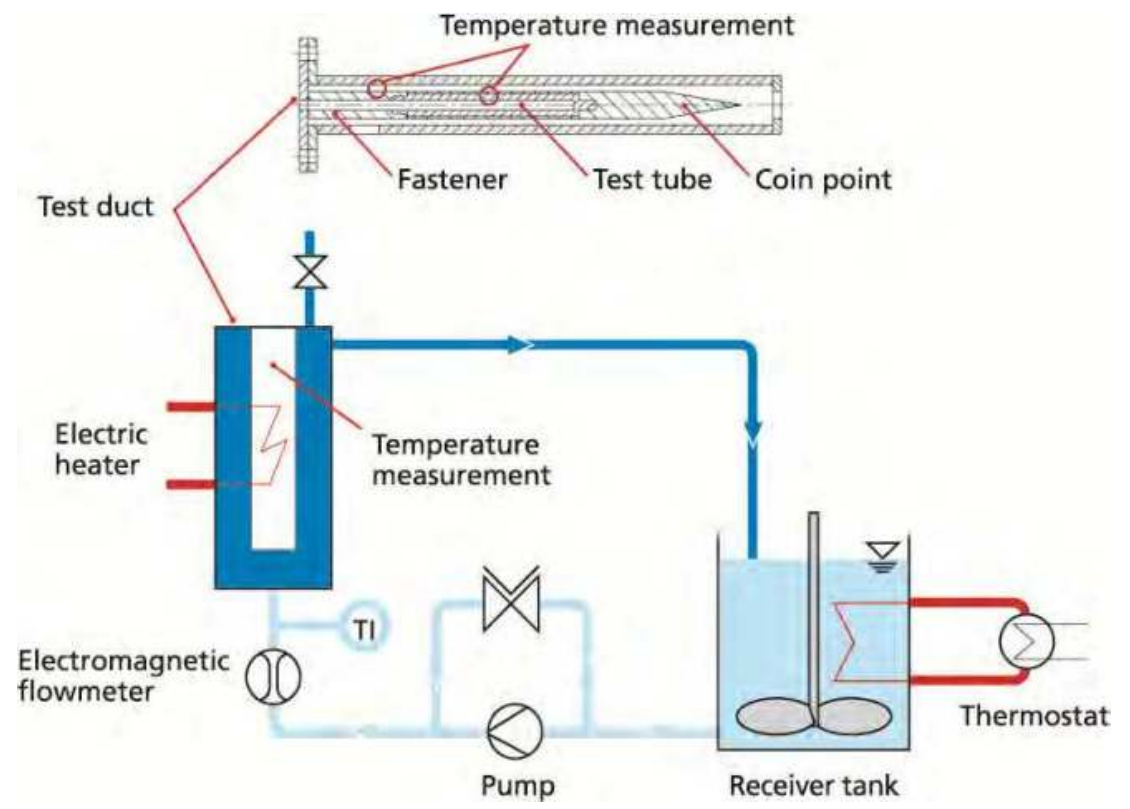

Fig. 9. Flowchart of laboratory heat exchanger apparatus (Institute of Environmental Process Engineering IUV, Universität Bremen).

For the experiments, a $10 \%$ (by weight) aqueous whey protein solution was set in the receiver tank. The solution was prepared by solving a whey protein concentrate WPC35 in water until the required concentration was obtained. The $\mathrm{pH}$ was adjusted to 6.0 using a 0.1 mol/liter $\mathrm{HCl}$ solution. Pre-heating was carried out to about $43{ }^{\circ} \mathrm{C}$. The solution was pumped in the closed cycle of the experimental setup, the electric heater of the test channel was activated and the measuring procedure was started. After each trial, the whey protein solution was replaced to exclude any effect of heating on the ingredients. After each run, the tube was cleaned with 0.1 molar $\mathrm{NaOH}$ solution with cross flow velocity of $0.6 \mathrm{~m} / \mathrm{s}$. The experimental parameters were:

Volumetric flow rate: $0.036-0.37 \mathrm{~m} 3 / \mathrm{h}$

Whey protein concentration: $10 \%$ (by weight)

Average flow velocity in annulus: $0.2 \mathrm{~m} / \mathrm{s}$

Fluid temperature (measuring section): $45^{\circ} \mathrm{C}$

Temperature of the heating element: $230^{\circ} \mathrm{C}$

Heat flux: $20 \mathrm{~kW} / \mathrm{m}^{2}$

Experimental time: 15 to $30 \mathrm{~min}$.

\subsubsection{Pilot plant testing}

Industrial tests with milk were carried out on a small plant by the Institute of Food Quality LUFA-Oldenburg-Germany, with the support of the company GEA PHE Systems (Figure 10). The pilot plant can produce almost all dairy products. It is used for training purposes as well as technological support and procedure development to the food industry. 


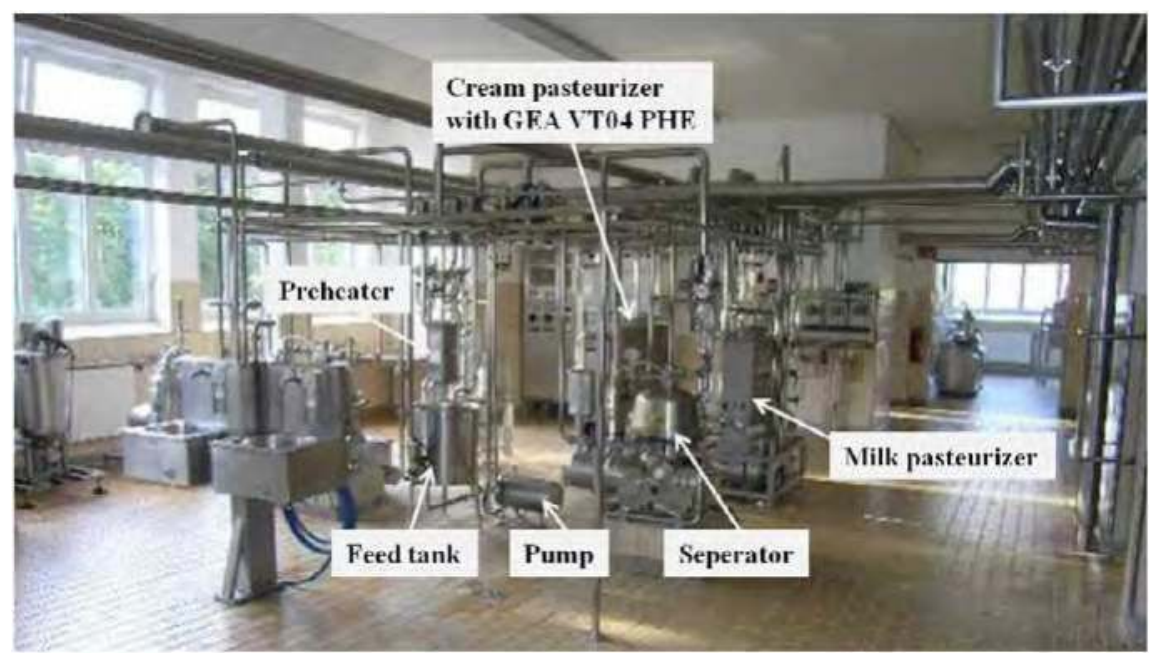

Fig. 10. Pilot plant used for practical tests (Institute of Food Quality LUFA-OldenburgGermany) with GEA Ecoflex VT04 plate heat exchanger.

The plate heat exchanger, in which coated and uncoated plates can be installed, consists of two cooling sections (deep cooler with 8 plates and pre-cooler with 10 plates), heat recovery section (with 12 plates), heating section (with 7 plates) and hot water section (with 6 plates). Before assembling the heat exchanger, selected plates in the heating and heat recovery sections were coated using the method described in section 3.2.1. As a reference, stainless steel, electro-polished and PTFE coated plates were also installed in the heat exchanger (Figure 11). Table 6 details the samples used and their specifications.

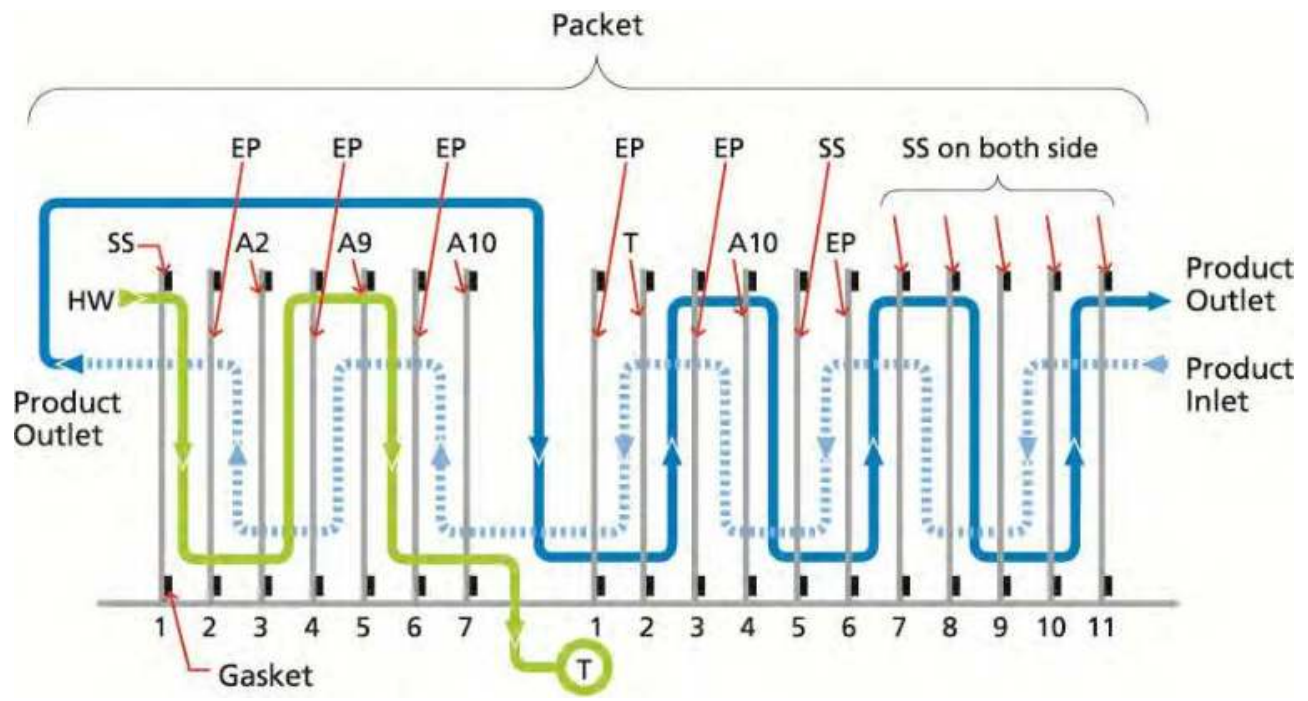

Fig. 11. Plates layout inside GEA Ecoflex VT04 plate heat exchanger. 


\begin{tabular}{|l|l|c|}
\hline Substrate & Material & Thickness $[\mu \mathrm{m}]$ \\
\hline SS & Stainless steel & - \\
\hline EP & Electrically-polished stainless steel & - \\
\hline A2 & Epoxy-resin based coating of INM & 83.7 \\
\hline A9 & Polyurethane based coating of INM & 53.0 \\
\hline A10 & Polyurethane based coating of INM & 85.2 \\
\hline A67 & Polyurethane based coating of INM & 27.6 \\
\hline PTFE & Teflon & 22.5 \\
\hline
\end{tabular}

Table 6. Samples specifications used in the pilot plant experiments by LUFA.

The milk was pumped from the receiver tank through the pasteurizer at a constant flow rate. The process steps of heating, cooling and heat recovery were combined together. After a working time of 4 hours, the test was stopped and the plates of the heater and heat recovery sections were removed in order to measure deposit formation. Visual observations and mass investigations were done. Furthermore, the cleaning effectiveness was assessed.

\subsection{Results and discussion}

Technical investigations were carried out by IUV and LUFA on the deposits formed from whey protein solution in both the laboratory facility and the pilot plant.

\subsubsection{Laboratory tests by IUV}

Laboratory investigations were carried out by IUV on the deposit of whey protein on the tube surface. Different stainless steel tubes were tested by IUV using the laboratory heat exchanger apparatus described in section 3.2. Figure 12 shows the deposit accumulation rates of whey protein solution for the different tube surfaces.

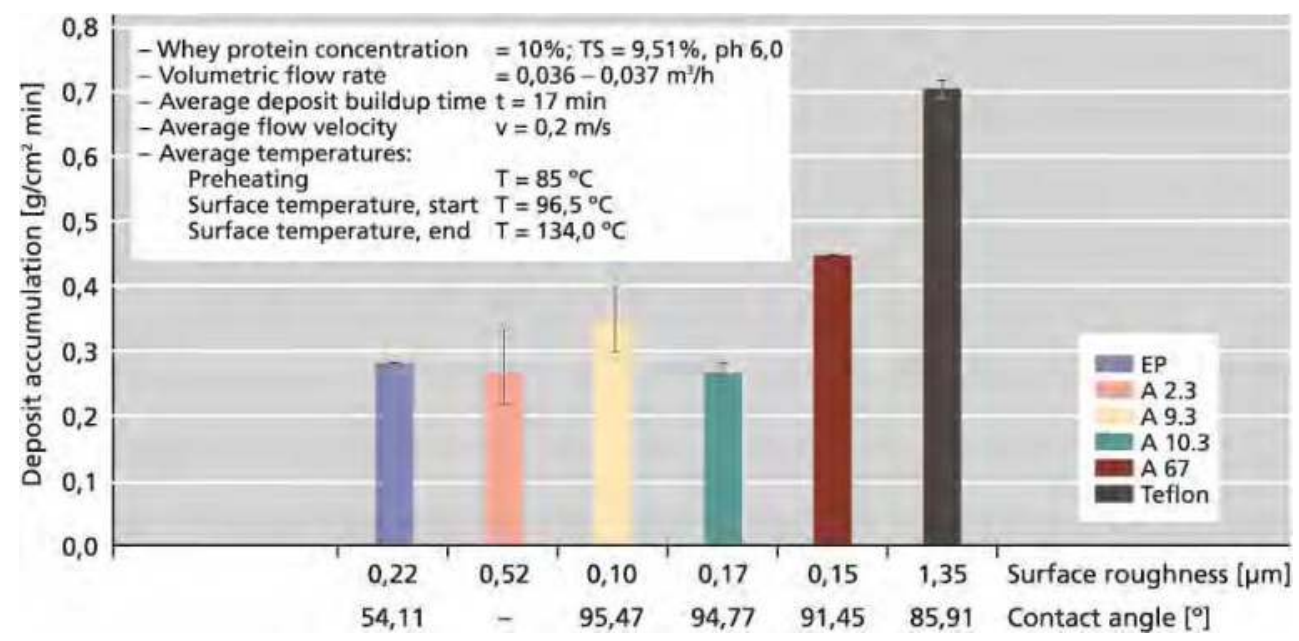

Fig. 12. Deposit accumulation rates for laboratory tests with whey protein on small coated cylindrical ducts. Plate characteristics are given in Table 6. 
The Polyurethane-coated tubes gave the thinnest deposit layer, closely followed by the electropolished tubes. The laboratory cleaning tests showed that under the same hydrodynamic conditions, the cleaning time for test tube A9 is only $20 \%$ of that needed for the standard stainless steel tube.

\subsubsection{Pilot plant tests by LUFA}

In a test series LUFA Nord-West in Oldenburg-Germany examined the formation of deposit on test PHE plates which had undergone different treatments. Different coated plates were installed in the heating section of a pasteurizer, with PTFE coated plates next to electropolished and standard stainless steel plates. The anti-fouling coatings were high-molecular polymers with implanted nano-particles which resulted in high hardness and scratch resistance. The pasteurizer was operated with a $10 \%$ (by weight) whey protein solution which was heated up to $85^{\circ} \mathrm{C}$. Figure 13 shows the amount of residue, in g, for different surfaces in three tests. It is noteworthy that in these test conditions there is significant whey protein deposition on uncoated, electro-polished and A2-coated stainless steel.

The coatings A2 and A10 showed reduced deposit buildup (the PTFE coating gave more deposit buildup than the standard stainless steel plate). The plates coated with A10 coating had the lowest adhesion, which was similar to the laboratory test results. The deposit buildup on the electro-polished plates was lower than the standard stainless steel plate and almost comparable to the coated plates. Cleaning studies indicated that the cleaning in place (CIP) time, for all coatings was shorter than that for the standard stainless steel plate: PTFE coated plates down by $90 \%$; coated plates down by $70 \%$; electro polished plates down by $36 \%$.

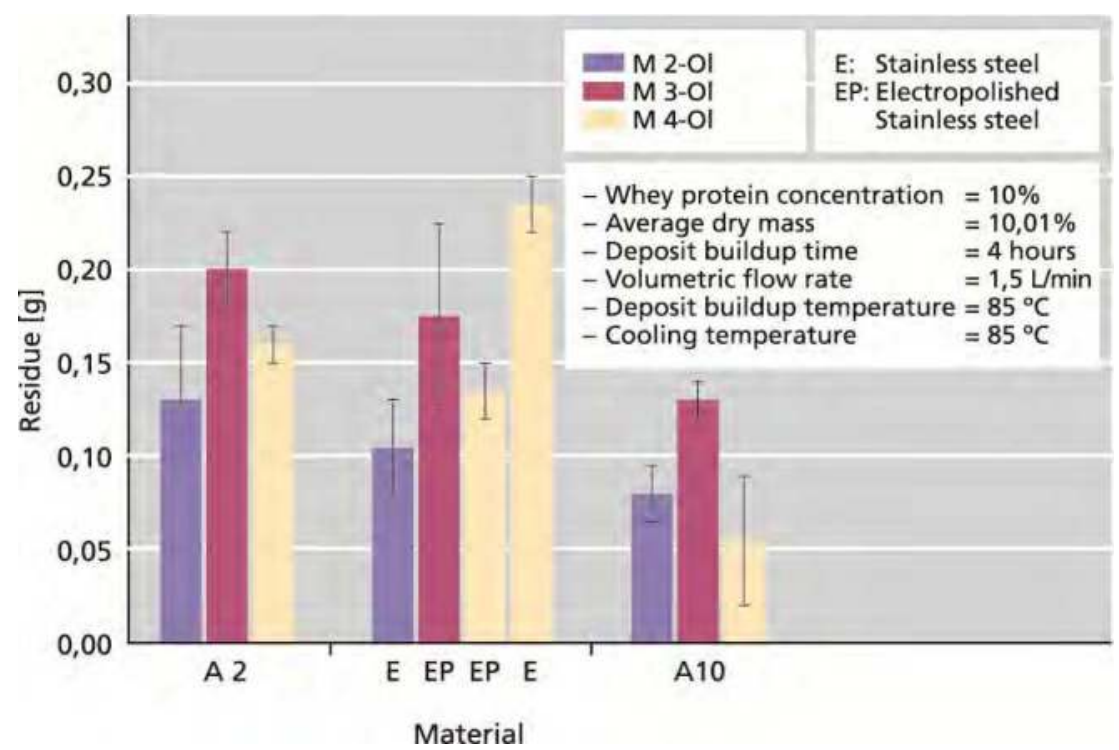

Fig. 13. Amount of deposits formed using whey protein solution, in three tests $(\mathrm{m} 2, \mathrm{~m} 3$ and $\mathrm{m} 4)$. 
Figure 14 shows photographs for two different coated plates from the heating section in the heat exchanger after different experimental runs (A2 on left and A10 on right).

It is evident that the coatings have been locally destroyed at the contact points, as pointed by the red circles in the figure. The flow in the plate gap causes relatively high vibrations with particularly strong stresses to the contact points, which is added to the high thermal stresses. The coatings at the present stage of development could not withstand these stresses and need further development.

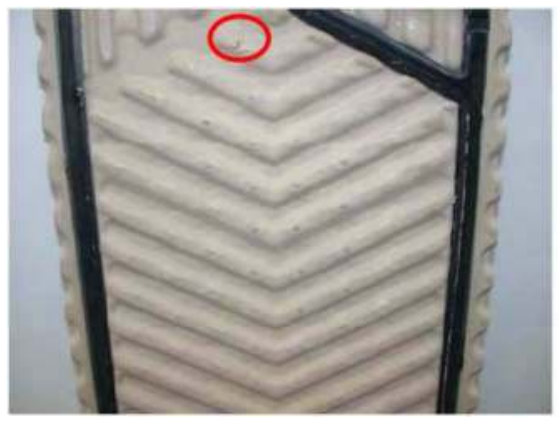

(a)

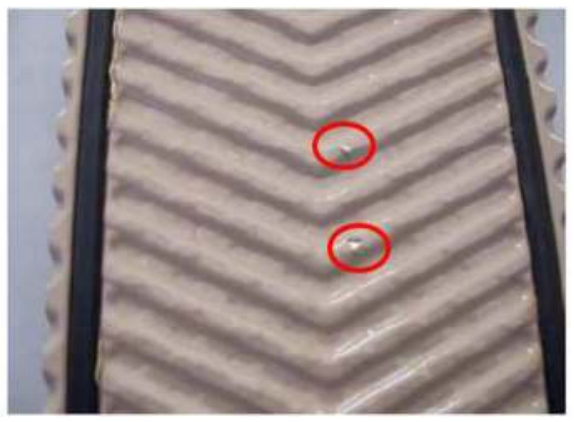

(b)

Fig. 14. Coated heat exchanger plates from heating section: (a) A2 coating, (b) A10 coating.

\subsection{Conclusions}

Nano-composites could be used as anti-fouling coatings to decrease fouling inside gasketed plate heat exchangers for the dairy industry. Industrial tests showed that the coatings A2 and A10 reduced fouling, though the PTFE coating showed higher fouling than the standard stainless steel plate. The deposit buildup on the electro-polished plates was lower than the standard stainless steel plates and almost comparable to the coated plates. A CIP time reduction was observed for all coatings: PTFE coated plates down by $90 \%$; nano-composites coated plates down by $70 \%$; electro polished plates down by $36 \%$. Pilot plant testing indicated the coatings must be further developed so that they can withstand the thermal and mechanical stresses which arise in industrial operation.

\section{Nomenclature}

$\begin{array}{ll}\text { CIP } & \text { Cleaning in place } \\ \text { EP } & \text { Electrically-polished stainless steel } \\ \text { INM } & \text { Institute of New Materials } \\ \text { IUV } & \text { Institute of Environmental Process Engineering } \\ \text { LUFA } & \text { Institute of Food Quality } \\ \text { NT } & \text { New technology } \\ \text { PCTFE } & \text { Polychlorotrifluorethylene } \\ \text { PHE } & \text { Plate heat exchanger } \\ \text { PTFE } & \text { Polytetrafluorethene (Teflon) } \\ \text { SS } & \text { Stainless steel } \\ \text { VT } & \text { Varitherm } \\ \text { XRF } & \text { X-ray Fluorescence }\end{array}$




\section{References}

Augustin, W., Geddert, T., Scholl, S. (2007). Surface treatment for the mitigation of whey protein fouling, Proceedings of 7 th International Conference on Heat Exchanger Fouling and Cleaning, pp. 206-214, ECI Symposium Series, Volume RP5Tomar, Portugal.

Bani Kananeh, A., Scharnbeck, E., Kück, U. D. (2009). Application of antifouling surfaces in plate heat exchanger for food production, Proceedings of 8th International Conference on Heat Exchanger Fouling and Cleaning, pp. 154-157, Schladming, Austria.

Bani Kananeh, A., Scharnbeck, E., Kück, U.D. and Räbiger, N. (2010). Reduction of Milk Fouling Inside Gasketed Plate Heat Exchanger Using Nano-Coatings. Food and Bioproducts Processing, Vol. 88, No. 4, (December 2010), pp. 349-356.

Bansal, B., Chen, X. D. (2006). A critical review of milk fouling in heat exchangers, Comprehensive Reviews in Food Science and Food Safety, Vol. 5, No. 2, (April 2006), pp. 27-33.

Beuf, M., Rizzo, G., Leuliet, J.C., Müller-Steinhagen, H., Yiantsios, S., Karabelas, A., Benezech, T. (2003). Fouling and cleaning of modified stainless steel plate heat exchangers processing milk products, Proceedings of ECI Conference on Heat Exchanger Fouling and Cleaning: Fundamentals and Applications, pp. 99-106, Vol. RP1, Article 14, Santa Fe, New Mexico, USA.

Delplace, F., Leuliet, J. C. and Tissier, J.P. (1994). Fouling experiments of a plate heat exchanger by whey proteins solutions, Transactions on IChemE C 72, pp.163-9.

Gerwann, J., Csögör, Z., Becker-Willinger, C. and Schmidt, H. (2002). Antimicrobic low surface-free energy nanocomposite coatings for medical applications, Proceedings of Hygienic Coatings Conference, Brussels.

Kukulka, D. J. and Leising, P. (2009). Evaluation of Surface Coatings on Heat Exchangers. Chemical Engineering Transactions, Vol.18, (May 2009), pp. 339-344.

Kück, U. D., Hartmann, D., Manske, S., Kück, A. and Räbiger, N. (2007). Entwicklung neuer Verarbeitungsprozesse für die Lebensmittelherstellung durch Anwendung von neuartigen funktionalen Materialoberflächen, AiF-Abschlußbericht (AiF-Nr. $14228 N / 1)$, Bremen.

Müller-Steinhagen, H. (1999). Cooling-Water Fouling in Heat Exchangers. Advances in Heat Transfer, Vol. 33, (1999), pp. 415-496.

Müller-Steinhagen, H. (2006). Verschmutzung von Wärmeübertragerflächen. In: VDIWärmeatlas Ausgabe 2006, Verein Deutscher Ingenieure and VDI- Gesellschaft Verfahrenstechnik und Chemieingenieurwesen (GVC), pp. (Od1-Od30), SpringerVerlag Berlin Heidelberg, Germany.

Pana-Suppamassadu, K., Jeimrittiwong, P., Narataruksa, P. and Tungkamani, S. (2009). Effects of Operating Conditions on Calcium Carbonate Fouling in a Plate Heat Exchanger. World Academy of Science, Engineering and Technology, No. 53, (May 2009), pp. 1204-1215.

Premathilaka, S. S., Hyland, M. M., X.D. Chen, X. D., Watkins, L. R., Bansal, B. (2007). Interaction of whey protein with modified stainless steel surfaces, Proceedings of 7 th International Conference on Heat Exchanger Fouling and Cleaning, pp. 150-121, ECI Symposium Series, Volume RP5, Article 21,Tomar, Portugal.

Uhde GmbH, Available from: <http:/ / www.uhde.eu/index_flash.en.epl>

Wang, L., Sunden, B, Manglik, R.M. (2007). Plate Heat Exchangers: Design, Applications and Performance, WIT Press, ISBN 978-1-85312-737-3, Southampton, Great Britain.

Zhao, Q., Liu, C., Liu, Y., Wang, S. (2007). Bacterial and protein adhesion on Ni-P-PTFE coated surfaces, Proceedings of 7 th International Conference on Heat Exchanger Fouling and Cleaning, pp. 237-242, ECI Symposium Series, Volume RP5, Article 33, Tomar, Portugal. 


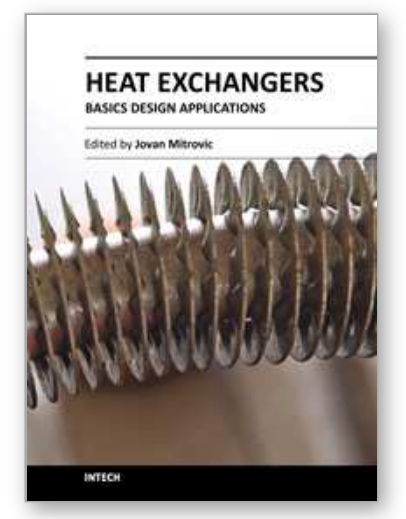

\author{
Heat Exchangers - Basics Design Applications \\ Edited by Dr. Jovan Mitrovic
}

ISBN 978-953-51-0278-6

Hard cover, 586 pages

Publisher InTech

Published online 09, March, 2012

Published in print edition March, 2012

Selecting and bringing together matter provided by specialists, this project offers comprehensive information on particular cases of heat exchangers. The selection was guided by actual and future demands of applied research and industry, mainly focusing on the efficient use and conversion energy in changing environment. Beside the questions of thermodynamic basics, the book addresses several important issues, such as conceptions, design, operations, fouling and cleaning of heat exchangers. It includes also storage of thermal energy and geothermal energy use, directly or by application of heat pumps. The contributions are thematically grouped in sections and the content of each section is introduced by summarising the main objectives of the encompassed chapters. The book is not necessarily intended to be an elementary source of the knowledge in the area it covers, but rather a mentor while pursuing detailed solutions of specific technical problems which face engineers and technicians engaged in research and development in the fields of heat transfer and heat exchangers.

\title{
How to reference
}

In order to correctly reference this scholarly work, feel free to copy and paste the following:

Ali Bani Kananeh and Julian Peschel (2012). Fouling in Plate Heat Exchangers: Some Practical Experience, Heat Exchangers - Basics Design Applications, Dr. Jovan Mitrovic (Ed.), ISBN: 978-953-51-0278-6, InTech, Available from: http://www.intechopen.com/books/heat-exchangers-basics-design-applications/fouling-in-plateheat-exchangers-some-practical-experience

\section{INTECH}

open science | open minds

\section{InTech Europe}

University Campus STeP Ri

Slavka Krautzeka 83/A

51000 Rijeka, Croatia

Phone: +385 (51) 770447

Fax: +385 (51) 686166

www.intechopen.com

\section{InTech China}

Unit 405, Office Block, Hotel Equatorial Shanghai

No.65, Yan An Road (West), Shanghai, 200040, China

中国上海市延安西路 65 号上海国际贵都大饭店办公楼 405 单元

Phone: $+86-21-62489820$

Fax: $+86-21-62489821$ 
(C) 2012 The Author(s). Licensee IntechOpen. This is an open access article distributed under the terms of the Creative Commons Attribution 3.0 License, which permits unrestricted use, distribution, and reproduction in any medium, provided the original work is properly cited. 